\title{
Molecular markers contribute to a breeding programme of the extinct-in-the-wild Alagoas Curassow Mitu mitu and confirm the validity of the species
}

\author{
ERWIN TRAMONTINI GRAU, SÉRGIO LUIZ PEREIRA, LUÍS FÁBIO \\ SILVEIRA and ANITA WAJNTAL
}

\begin{abstract}
Summary
Alagoas Curassow Mitu mitu is considered extinct in the wild, having previously inhabited a small area in north-eastern Brazil that has since been replaced by sugar cane farms. Around 50 birds possessing morphological features of this species are still alive in captivity in Brazil, all being descendants from a breeding programme started in 1979, using offspring from a single male and two females captured from the wild. However, this captive population also includes some hybrids with the congeneric Razor-billed Curassow M. tuberosa and their descendants. Furthermore, the validity of Alagoas Curassow as a species is questionable. We used two molecular markers to study the validity of this taxon as a species, to detect potential hybrids present in the stock, and to estimate genetic variability among the remnant specimens. The analysis of 760 base pairs from mitochondrial cytochrome $b$ and control region sequences revealed that at least three of the 20 birds analysed had sequences identical to those of Razor-billed Curassow. The other 17 birds presented sequences that diverged 2.6\% from Razor-billed Curassow. Moreover, a sample from an Alagoas Curassow museum skin collected from the wild in 1951 had cytochrome $b$ sequences identical to those of the 17 birds. These results confirm the Alagoas Curassow as a valid species. DNA fingerprinting profiles of the 20 descendants from the Alagoas Curassow breeding population showed that this group of birds is depauperate in genetic variability. There was an increase in genetic variability of birds born after 1990, attributed to the hybrid mating of Alagoas Curassow with Razor-billed Curassow. We suggest that birds born before 1990 should be handled separately from the others. However, if a decrease in chick harvest among birds of this group is detected due to inbreeding depression or ageing, cross-breeding between this group and the group of birds most closely related to it should be considered in order to enrich the progeny with the Alagoas Curassow genome.
\end{abstract}

\section{Introduction}

Most cracids are endemic to the Neotropics, and are important bioindicators of the health of their habitat (Brooks and Strahl 2000). The family encompasses 11 genera and approximately 50 species. Among these latter, 19 species are listed as Vulnerable, Endangered or Critically Endangered, mainly due to excessive hunting and habitat destruction (Brooks and Strahl 2000, BirdLife International 2000). The most threatened species of this family is Alagoas Curassow Mitu mitu. 
Its former habitat was the Atlantic Forest in the state of Alagoas, north-eastern Brazil, but the last large forest remnants were replaced by sugar cane in the $1970 \mathrm{~s}$ and 1980s. Its population size was estimated at less than 60 individuals in the late 1970s (Teixeira 1986) but now this species is considered extinct in the wild (Collar et al. 1992, BirdLife International 2000, L. F. Silveira unpublished data).

Linnaeus described the Alagoas Curassow in 1766, naming it Crax mitu, based on texts and illustrations published in 1648 by the German naturalist J. Marcgrave, in his famous "Historia Rerum Naturalium Brasiliae" (Teixeira 1992). For about three centuries, the species was not recorded in the wild, until Oliverio Pinto captured a single female in 1951. This specimen is now housed at the Museu de Zoologia da Universidade de São Paulo, (MZUSP ${ }^{\circ}$ 37.188) in São Paulo, Brazil. Despite being considered a monotypic species (Collar et al. 1992, Nardelli 1993, del Hoyo et al. 1994, Sick 1997), many ornithologists have questioned its validity as a species, mainly because of its rarity and morphological similarity to Razor-billed Curassow M. tuberosa, an inhabitant of the Amazon Forest (Pinto 1952, Coimbra-Filho 1970, Sick 1980). Silveira (unpublished data) compared the single adult female specimen of Alagoas Curassow, collected in 1951, with nine females of the closely related Razor-billed Curassow and confirmed the validity of the former as a full species based on diagnostic characters of a bi-coloured bill, a bare auricular patch and a tail with buff rather than white tips and nearly all-black central rectrices.

In 1979, five birds were collected from the wild in the municipality of Barra de São Miguel ( $\left.0^{\circ} 50^{\prime} \mathrm{S}, 35^{\circ} 54^{\prime} \mathrm{W}\right)$, Alagoas, Brazil, to be used in a captive breeding programme (Nardelli 1993). At the time of writing, all surviving birds are descendants of this breeding programme developed by Nardelli (1993) who successfully bred two females with a single male. In 1990, after the death of this single male, Nardelli began to cross some Alagoas Curassows with Razor-billed Curassows. After a deplorable misunderstanding between the breeder and official authorities, the original records of the breeding data became unavailable. Thus, only the birds that were born before 1990 can be considered as "pure" Alagoas Curassow. In 2000, the whole population of surviving birds (44 birds) was split between two different breeders. We had the opportunity to collect blood samples from the 20 birds held by one breeder. This group consisted of three birds born before 1990 and 17 born after.

To evaluate the status of Alagoas Curassow as a species and to detect hybrid birds, we sequenced fragments of the mitochondrial control region and cytochrome $b$ genes of 20 birds possessing morphological features diagnostic of Alagoas Curassow and compared their sequences to those of other valid congeners. Similar procedures based on mtDNA sequences have been used by other researchers to ascertain specific status of birds and mammals (Zink and Blackwell-Rago 2000, Bradley and Baker 2001). In cracids, this approach has been applied before among several species of curassow, to check the validation of Crax viridirostris and C. estudilloi described solely on the basis of single specimens. In this case, the sequences of $C$. viridirostris and C. estudilloi were found to be identical to those obtained for Blue-billed Curassow C. alberti and Yellow-knobbed Curassow $C$. daubentoni substantially diminishing the possibility that they are valid species (Joseph et al. 1999). 
We also sequenced $166 \mathrm{bp}$ of the cytochrome $b$ from a skin fragment extracted from a museum specimen of Alagoas Curassow collected from the wild in 1951, to evaluate if the sequences obtained for most of the studied birds represented the sequence from this species.

The genetic variability of the 20 Alagoas Curassows was estimated utilizing DNA fingerprinting techniques, which have proved useful in estimating overall genetic variability in many groups of birds, including gallinaceous birds (Hanotte et al. 1992) and Cracidae (Pereira et al. 1996, Pereira and Wajntal 1999, 2001a,b). Based on the results obtained in this study, we present management recommendations in order to ameliorate further degradation of genomic variability in the captive population of Alagoas Curassow.

\section{Materials and methods}

Taxa

Approximately $0.1 \mathrm{ml}$ of blood was taken by venipuncture from 20 birds belonging to Nardelli's original stock. All these birds possessed phenotypic characteristics of Alagoas Curassow. Blood samples were also taken from three Razor-billed Curassows and one Crestless Curassow, M. tomentosa and kept in $0.5 \mathrm{ml}$ of absolute ethanol at room temperature. All birds sampled were from private aviaries. A skin sample of Alagoas Curassow was obtained from the Museu de Zoologia da Universidade de São Paulo (MZUSP $n^{\circ}$ 37.188) in São Paulo, Brazil. All specimens of Alagoas Curassow found in other museums and private collections have been donated by Nardelli from his captive breeding programme, and were not considered in this study.

\section{DNA sequencing from blood samples}

DNA was extracted from the 24 blood samples following standard protocols (Sambrook et al. 1989). Two mitochondrial DNA fragments were isolated by polymerase chain reaction (PCR) with primers Dloop L (5'-TTG TTC TCA ACT ACG GGA AC-3') and Dloop H (5'-GTG AGG TGG ACG ATC AAT AAA T-3') for the first domain of the control region (G. Rowe, pers. comm.) and primers reverse cyt $b$ L (Kornegay et al. 1993) and CBH15764 (Miyaki et al. 1998) for the cytochrome $b$. DNA amplification was performed in $10.0 \mu \mathrm{l}$ of $2.0 \mathrm{mM}$ of each dNTP, 10.0 $\mu \mathrm{M}$ of each primer, 1-50 ng of genomic DNA, 0.5 U of Taq DNA polymerase (Amersham Pharmacia Biotech) and 1.o $\mu$ l of buffer 10X supplied with Taq DNA polymerase. The reaction was performed for $5 \mathrm{~min}$ at $95{ }^{\circ} \mathrm{C}$ for denaturation, followed by 30 cycles of $95{ }^{\circ} \mathrm{C}$ for $40 \mathrm{~s}, 54{ }^{\circ} \mathrm{C}$ for $30 \mathrm{~s}$, and $72{ }^{\circ} \mathrm{C}$ for $30 \mathrm{~s}$, and a final extension of 10 min at $72{ }^{\circ} \mathrm{C}$. Products were purified with $15 \mathrm{U}$ of exonuclease I (USB) and $1.5 \mathrm{U}$ of shrimp alkaline phosphatase (USB) for 60 min at $37^{\circ} \mathrm{C}$ followed by $10 \mathrm{~min}$ at $80^{\circ} \mathrm{C}$. Sequencing reactions and purifications were performed according to the manufacturer's recommended protocol (Big Dye terminator cycle sequencing kit; Applied Biosystems) and loaded in an automated DNA sequencer ABI Prism 377 (Applied Biosystems). Both strands of each DNA fragment were sequenced. 


\section{DNA sequencing from skin sample}

All procedures for DNA extraction and sequencing of the skin fragment from the museum specimen were done in a laboratory where bird samples had not been manipulated, to avoid contamination. DNA was extracted using QIAamp DNA Mini Kit as recommended by the manufacturer (Qiagen Inc.). We performed two concomitant extractions, one containing fragments of the skin sample and the other performed without any DNA source, to verify that there was no possible contamination. New reagents were used in these isolations. A fragment of the cytochrome $b$ was amplified by PCR, with primers CBH15764 (Miyaki et al. 1998) and CBL15562 (5'-TAT TTC TCC YTA AAA GAC CTG TTA GGG TT-3', C. Y. Miyaki pers. comm.) in the same conditions as described above for DNA extracted from blood samples. Following this, a second amplification was performed in the same conditions using $2 \mu \mathrm{l}$ from the first reaction, for both the previous reactions containing the museum skin and the one without any DNA source. Sequencing reaction and purification were performed as described for blood samples and loaded in an automated DNA sequencer ABI Prism 377 (Applied Biosystems).

\section{Sequences analysis}

Both strands of the DNA fragments of each bird were visually aligned and corrected for ambiguities in Sequence Navigator (Applied Biosystems). The control region and cyt $b$ sequences of each bird were concatenated before further analysis. The cyt $b$ sequence from the skin sample was visually aligned with the corresponding cyt $b$ sequences obtained from the other 24 birds. Uncorrected p-distances were estimated in PAUP 4.ob8 (Swofford 2001). Sequences obtained in this study have been deposited in GenBank under accession numbers AYo98533-AYo98580.

\section{DNA fingerprinting}

Multilocus DNA fingerprints were performed as described in Bruford et al. (1992). Briefly, $4 \mu \mathrm{g}$ of genomic DNA from each of the 20 captive Alagoas Curassows was completely digested with 15 units of $M b o$ I for a period of $16-18 \mathrm{hrs}$. The fragments were electrophorized through a $30-\mathrm{cm}$ long horizontal $1 \%$ agarose gel, until the $\gamma$-HindIII molecular marker of $2.3 \mathrm{~kb}$ loaded in the first lane had migrated to the anodal end of the gel. Digested DNA sample of the same bird was loaded in the second and in the last lane of the gel to estimate band migration distortion and provide a better scoring of the bands. The fractionated DNA fragments were transferred onto a nylon membrane (Hybond Nfp, Amersham) by capillary Southern blotting (Sambrook et al. 1989).

The human multilocus minisatellite probe 33.15 (Jeffreys et al. 1985a) was radiolabelled by the random priming method with $\left[\alpha-{ }^{32} \mathrm{P}\right] \mathrm{dCTP}$. The membrane was pre-hybridized for one hour at $65^{\circ} \mathrm{C}$ in a solution containing only $0.263 \mathrm{M}$ $\mathrm{Na}_{2} \mathrm{PO}_{4}$ and $7 \%$ SDS. The probe was added to this solution and left overnight at the same temperature. The membrane was then washed in $2 \times$ SSC, $0.1 \%$ SDS and in $1 \times$ SSC, $0.1 \%$ SDS at $65^{\circ} \mathrm{C}$, for $20 \mathrm{~min}$ each. Autoradiographs were 
Table 1 . Variable sites found in the 24 curassows sampled. Numbers are written vertically and correspond to position in the mtDNA sequence analysed. Dots and a dash represent, respectively, the same base and a gap in the sequence related to the most frequent Alagoas Curassow haplotype shown on the top.

\begin{tabular}{|c|c|c|c|}
\hline Species & $\begin{array}{l}\text { Number } \\
\text { of birds }\end{array}$ & Control region haplotype & Cyt $b$ haplotype \\
\hline & & OOOII1222223333333 & OOO11122233333 \\
\hline & & 158359022581111223 & 18806923812245 \\
\hline & & 376661879834567451 & 11344149113674 \\
\hline Alagoas Curassow & 16 & TGGTCTCCCCCAGCTTAC & GTATCTCCGTCCAT \\
\hline Alagoas Curassow & 1 & $\ldots \ldots \ldots \ldots$ & $\ldots \ldots \ldots$ \\
\hline Alagoas Curassow & 3 & ...C.CAT . TTGA. . .GT & ACGC.CTTACT . . . \\
\hline Razor-billed Curassow & 3 & . . .C.CAT . TTGA . . .GT & ACGC.CTTACT . . . \\
\hline Crestless Curassow & 1 & CA-CT . . TT TT . . TCC . . & A .GCTCTT.C.TGC \\
\hline
\end{tabular}

obtained after one to three days of exposure at $-80{ }^{\circ} \mathrm{C}$ using X-ray film and two intensifying screens.

Bands in the range of 3.8 to $15.5 \mathrm{~kb}$ were marked on acetate overlays according to Westneat (1990). The band-sharing coefficient (BSC), or index of similarity, between individuals was calculated as: $x=2 N_{\mathrm{AB}} /\left(N_{\mathrm{A}}+N_{\mathrm{B}}\right)$ where $N_{\mathrm{AB}}$ is the number of bands shared by $A$ and $B, N_{\mathrm{A}}$ and $N_{\mathrm{B}}$ are the number of bands present in birds $A$ and $B$, respectively (Wetton et al. 1987, Bruford et al. 1992). The genetic variability was therefore the reciprocal of the index of similarity. Assuming that the bands scored were independent markers, the mean probability that all $n$ bands in an individual's fingerprint were present by chance in a second random unrelated individual was conservatively estimated as $<X^{\mathrm{n}}$ (Jeffreys et al. $1985 \mathrm{~b}$, Bruford et al. 1992). Mean heterozygosity $(\mathrm{H})$ was given by $\mathrm{H}=2 \mathrm{q}(1-\mathrm{q}) /\left(2 \mathrm{q}-\mathrm{q}^{2}\right)$ (Sundt et al. 1994), where q, the mean allelic frequency of bands, is obtained from $x=2 \mathrm{q}-\mathrm{q}^{2}$ (Jeffreys et al. 1995b).

\section{Results}

\section{DNA sequencing}

Amplification of each mitochondrial DNA region resulted in single PCR products for each bird. From these PCR products we obtained unambiguous sequences with similarity to corresponding sequences of other birds deposited in GenBank. The reading frame for cytochrome $b$ sequences did not show any stop codon or changes in amino acid sequence that could indicate that they were of nuclear instead of mitochondrial origin. Contamination did not occur as no amplification was observed in the negative control reactions.

The concatenated sequences obtained for each of the 24 birds were $760 \mathrm{bp}$ long ( $390 \mathrm{bp}$ for cytochrome $b$ and $370 \mathrm{bp}$ for control region). Thirty-two variable sites were found (Table 1 ). The sequences from the Razor-billed and the Crestless Curassows differed by $2.8 \%(21 / 760)$. Three different haplotypes were found in the 20 birds presumed to be Alagoas Curassow on the basis of phenotypic characteristics. Three individuals among 20 individuals of Alagoas Curassow had sequences identical to those of Razor-billed Curassow. Among the other 17 individuals, 16 possessed identical haplotypes, including two birds born before 
1990, and a single male born in 1984 differed by a single transition nucleotide substitution in the control region. Uncorrected $p$-distance between the haplotypes of Alagoas and Razor-billed Curassows was 2.6\% (20/760) and between Crestless and Alagoas Curassows was 3.0\% (23/760).

The cytochrome $b$ fragment obtained from the skin sample had a size of 202 $\mathrm{bp}$, producing an analysable sequence of $166 \mathrm{bp}$ that was found to be identical to those 17 birds presenting the most common haplotype. This sequence differed by $2.4 \%$ (4/166) from Razor-billed Curassow and by 3.0\% (5/166) from Crestless Curassow sequences.

\section{DNA fingerprinting}

The mean number of bands detected by the human multilocus minisatellite probe 33.15 for the 20 captive-kept Alagoas Curassows was $14.4 \pm 3.2$ (range from 9 to 16 bands). Among these an average of $5.2 \pm 2.1$ fragments were shared, providing an average BSC of $0.358 \pm 0.12$. Considering only the birds born before 1990 (prior to the inclusion of Razor-billed Curassow in the breeding programme) the mean BSC was $0.501 \pm 0.17$. After Razor-billed Curassows were introduced in the breeding programme, the mean BSC decreased to $0.354 \pm 0.12$. Excluding the three Alagoas Curassows whose mitochondrial DNA sequences were identical to that of Razor-billed Curassow (see above), the mean BSC was $0.327 \pm 0.11$. The probability of two unrelated birds sharing identical profiles by chance was extremely remote and had a probability in the order of 1 in $10^{-5}$ to $10^{-7}$. Mean heterozygosity was lower for birds born before $1990(\mathrm{H}=0.82)$ compared with those born after this date $(\mathrm{H}=0.89)$.

\section{Discussion}

Is the Alagoas Curassow Mitu mitu a valid species?

The status of Alagoas Curassow as a species has been questioned in the last three centuries mostly because of its rarity and morphological similarity to Razor-billed Curassow (Pinto 1952, Coimbra-Filho 1970, Sick 1980). Our research addressed this question, which is of extreme importance for the management of this highly endangered taxon, by comparing the distances of mitochondrial genes between three different but closely-related lineages of the genus Mitu: Alagoas Curassow, Razor-billed Curassow and Crestless Curassow. The estimated distance of $2.6 \%$ between Alagoas and Razor-billed Curassow is almost the same as that between Alagoas and Crestless Curassow (3.0\%), as well as between Razor-billed and Crestless Curassow (2.8\%). Similar divergence for these same two mitochondrial DNA regions has been found between other recognizable congeneric species of the family Cracidae: $1.3 \%$ between Bare-faced Curassow Crax fasciolata and Black Curassow C. alector; 2.6\% between Bare-faced Curassow and Red-billed Curassow C. blumenbachii; and $1.4 \%$ between Chestnut-bellied Guan Penelope ochrogaster and Duskylegged Guan P. obscura (E. T. Grau unpubl. data). Distances equivalent or higher than the distance between valid species should help to validate questionable congeneric species (Zink and Blackwell-Rago 2000, Bradley and Baker 
2001). Thus, as Crestless Curassow is clearly a distinct species from the other two and the distances between the three species are almost equivalent, our data favour the hypothesis that Alagoas Curassow is indeed a distinct species from Razor-billed Curassow. Moreover, the findings presented here are concordant with sequence data collected from other mitochondrial genomic regions that show the uniqueness of the Alagoas Curassow when compared with 13 other recognizable curassow species (S. L. Pereira and A. J. Baker subm.).

\section{Interspecific hybridization}

Our DNA sequencing results showed that three birds of the breeding programme born after 1990 have mitochondrial sequences identical to Razor-billed Curassow. In addition, our DNA fingerprinting results showed an increase in the genetic variability among the birds born after 1990. Taken together, these results constitute strong evidence that hybridization has occurred between Alagoas and Razor-billed Curassows after 1990. Since mitochondrial DNA is maternally transmitted, our findings confirm that hybridization occurred between females of Razor-billed Curassow and males of Alagoas Curassow, and that at least one female Razor-billed Curassow was involved in the breeding. It would be useful to detect the ancestral male genome as well; however, the necessary tools are not available to us at present.

\section{Management}

Our DNA fingerprinting results showed that the birds born before 1990, which we are assuming to represent "pure" Alagoas Curassows, had a similarity index expected for first-degree relatives. This result is not surprising since all birds alive today are the outcome of only three birds captured from the wild (one male and two females). The increase in the genetic variability detected after 1990 to levels found for other non-threatened curassows (Pereira and Wajntal 1999, 2001a,b) can be attributed to the crosses of Alagoas Curassow with Razor-billed Curassow in captivity (Nardelli 1993). The best management programme for the conservation of Alagoas Curassow should include all surviving birds, especially those with a "pure" Alagoas Curassow background. The programme should aim to preserve the genetic constitution present in the "pure" surviving birds, but should also carefully consider the potential ill-effects that can arise due to inbreeding, such as decreased fertility and survival, as well as other possible effects due to the greater age of the three birds born before 1990. It is also possible that the surviving birds have already overcome the effects of inbreeding depression in a similar way as achieved experimentally in Speke's gazelle Gazella spekei as reported by Templeton and Read (1983). They demonstrated that after several rounds of consanguineous matings, there was a reduction in lethal equivalents in the outcome of inbred parents as compared with that of non-inbred parents. As a practical result, the reduction in inbreeding depression resulted in decreased mortality rates and increased birth weight of the offspring, demonstrating that animals can quickly adapt to even extreme inbreeding and that this adaptation can occur in relatively small populations. 
However, as the breeding success among the "pure" Alagoas Curassows cannot be assured and the genetic constitution of the remaining birds is unknown, the best strategy available at this time is to detect the birds that, through the technology used in the present work, showed the higher similarity with the "pure" birds, with similarity indexes higher than 0.5. Analysing the data in Table 2, it is possible to identify a group of two males and three females that show high genetic similarity to the birds born before 1990 (BSC $=0.577 \pm$ 0.03 ) as well as between males and females from this group (BSC $=0.624 \pm 0.02$ ). Mating between these selected birds has a higher chance of preserving most of the Alagoas Curassow genome than other matings and the outcome of these couples, or between them and the "pure" Alagoas Curassows, should be encouraged. It is interesting to point out that similarity indices between these selected birds and the birds that inherited a Razor-billed Curassow mitochondrial genome are much lower (BSC $=0.297 \pm 0.05$ ), as expected for birds that have an enriched Alagoas Curassow constitution when compared with birds with the Razor-billed Curassow contribution.

Three birds born after 1990 had DNA sequences and morphological features of Alagoas Curassow but a BSC > 0.5 with the three "hybrid" birds and a BSC of $0.283 \pm 0.07$ when compared with those three "pure" birds born before 1990.

Thus, among the 20 birds, three are "pure" Alagoas Curassow, five have a higher probability of also being pure or having a higher contribution of the Alagoas Curassow genome and 12 may be considered as being of mixed genomic constitution between Alagoas and Razor-billed Curassow genomes. The lower indices in comparison with the pure or selected group probably represent a higher contribution of the Razor-billed Curassow genome, but as those 12 birds have the typical morphological features of Alagoas Curassow, they certainly harbour some of the original Alagoas Curassow genome. Thus, they should not be excluded from the programme, as the main objectives are the preservation of most of the genetic constitution of this extinct-in-the-wild species as well as to try to establish a viable population in protected areas within its original distribution.

We have previously shown that the lack of genetic variability was not a problem for the establishment of a wild population of two other cracid species, Dusky-legged Guan and Rusty-margined Guan P. superciliaris in reforested areas (Pereira and Wajntal 1999). However, the success of establishing a viable population in the wild by reintroducing captive-bred birds with low genetic variability is unpredictable (Rave et al. 1994, Rave 1995, Tegelstrom and Sjoberg 1995). These birds and their descendants would appear to be limited in their ability to adapt to habitat and climatic variations and moreover it seems unlikely that natural selection could improve this condition because of the genetic uniformity of this population. Thus, the progeny of the 12 birds with both variable contributions from the Alagoas Curassow genome and with a high genetic variability, might represent in the future an important contribution to the reintroduction programme, in the same way that the introgression of foreign genetic contribution seems to have been important for preserving the Florida panther genome (Roelke et al. 1993). 
Species validity and conservation biology of $\mathrm{M}$. mitu

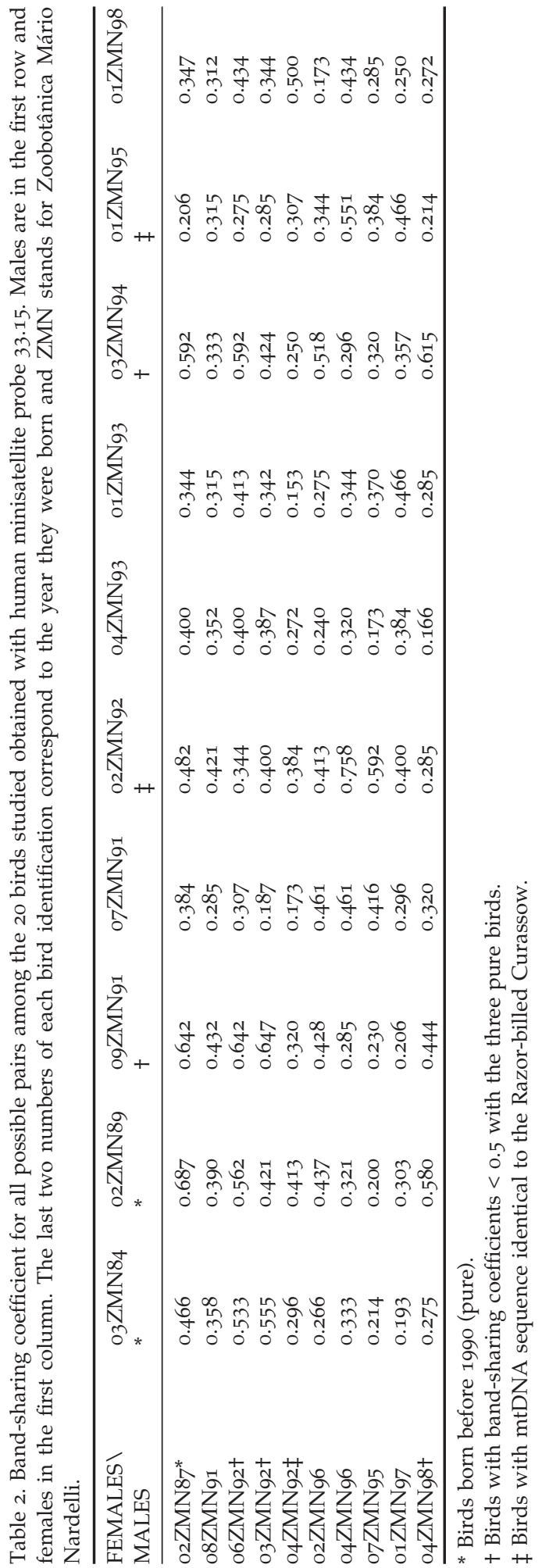




\section{Habitat availability for reintroduction}

During September and October 2001 one of us (LFS) and field ornithologist Fábio Olmos conducted surveys in forest fragments in Alagoas State. The objective was to assess the conservation status of the selected fragments, search for some north-eastern Atlantic Forest endemics and try to gather evidence of the survival of Alagoas Curassow in the wild.

The results (Silveira and Olmos unpublished data) showed that most remnants of forest are small and are restricted to steep valleys, which have proven to be unsuitable for sugar cane plantations, or have been preserved intentionally to keep water resources intact. However, intensive hunting and selective logging are common in these remaining forest fragments. Despite their efforts, no evidence of the existence of Alagoas Curassow was found.

However, some fragments of mature forest were discovered, the best conserved being that located at Fazenda Petrópolis in Usina Santo Antônio, a sugar cane plantation. This fragment has many freshwater creeks and fruit trees and would seem to be a suitable habitat that should be considered for a reintroduction programme for Alagoas Curassows.

A reintroduction programme, however, takes time to be effectively implemented. The owners of the selected areas (despite being private or government owned, e.g. state parks or reserves) must guarantee real protection, and an educational programme must be implemented involving the local population, before one can begin a reintroduction programme. The reintroduction of cracids in Brazil has been successful previously (Pereira and Wajntal 1999, R. Azeredo pers. comm.), and one can use these examples as an incentive for the re-establishment of a population of the Alagoas Curassow in its original habitat.

\section{Acknowledgements}

The authors thank Moacyr de Carvalho Dias for blood samples of 20 M. mitu, one $M$. tuberosa and one M. tomentosa; Roberto Azeredo for blood samples of two M. tuberosa. Dr Cristina Y. Miyaki, Maryann L. Burbidge, Dr Eugene Harris, Dr Paulo A. Otto, Dr Seb Buckton and an anonymous referee provided valuable suggestions. This work was performed with grants from FAPESP and CNPq. Dr Marie-Anne van Sluys (Department of Botany, University of São Paulo) kindly allowed the use of her laboratory to manipulate the sample of the museum skin. The Jeffrey's probe 33.15 is the subject of patent number GBA 2166445 and worldwide patents (pending) for commercial diagnostic use. Fieldwork in Alagoas was supported by BirdLife International, Neotropical Bird Club, Wetland Fund, WPA and ZGAP. Our tanks to Jaqueline Goerck and Nigel Collar for raising the necessary funding and to the Manomet Bird Observatory (Birder's Exchange) for donating field equipment. Field surveys in Alagoas were possible thanks to Fernando Pinto (IPMA), Marcelo Souza, S/A Usina Coruripe Açúcar e Álcool (Cícero Almeida e Magno Túlio Madeiro); Usina Leão S/A, Vila Utinga (John William Buyers Júnior), Usina Cachoeira (Leonardo Pinto Costa); Usina Serra Grande (Clodoaldo José Bakker); Usina Camaragibe (Cláudia Maranhão) and João Maram. 


\section{References}

BirdLife International (2000) Threatened birds of the world. Barcelona and Cambridge, U.K.: Lynx Editions and BirdLife International.

Bradley, R. D. and Baker, R. J. (2001) A test of the genetic species concept: cytochrome-b sequences and mammals. J. Mammal. 82: 960-973.

Brooks, D. M. and Strahl, S. D., compilers (2000). Curassows, Guans and Chachalacas. Status survey and conservation action plan for Cracids 2000-2004. Cambridge, U.K.: IUCN/SSC Cracid Specialist Group. IUCN Publication Services Unit.

Bruford, M. W., Hanotte, O., Brookfield, J. F. Y. and Burke, T. (1992) Single-locus and multilocus DNA fingerprinting. Pp. 225-269 in A. R. Hoelzel, ed. Molecular genetic analysis of populations. a practical approach. New York: IRL Press and Oxford University Press.

Coimbra-Filho, A. F. (1970) Sobre Mitu mitu (Linnaeus, 1766) e a validez das suas raças geográficas (Cracidae, Aves) Rev. Brasil. Biol. 30: 101-109.

Collar, N. J., Gonzaga, L. P., Krabbe, N., Madroño Nieto, A., Naranjo, L. G., Parker III, T. A. and Wege, D. C. (1992) Threatened birds of the Americas. The ICBP/IUCN red data book. Third edition, part 2. Washington, D.C.: Smithsonian Institution Press.

del Hoyo, J., Elliott, A. and Sargatal, J., eds. (1994) Handbook of the birds of the world, 2. New World vultures to guineafowl. Barcelona: Lynx Editions.

Hanotte, O., Bruford, M.W. and Burke, T. (1992) Multilocus DNA fingerprinting in gallinaceous birds: general approaches and problems. Heredity 68: 481-494.

Jeffreys, A. J., Wilson, V. and Thein, S. L. (1985a) Hypervariable 'minisatellite' regions in human DNA. Nature 314: 67-73.

Jeffreys, A. J., Wilson, V. and Thein, S. L. (1985b) Individual-specific 'fingerprinting' of human DNA. Nature 316: 76-79.

Joseph, L. Slikas, B., Rankin-Baransky, K., Bazartseren, B., Alpers, D. and Gilbert, A. E. (1999) DNA evidence concerning the identities of Crax viridirostris Sclater, 1875, and C. estudilloi Allen, 1977. Ornit. Neotrop. 10: 129-144.

Kornegay, J. R., Kocher, T. D., Willians, L. A. and Wilson, A. C. (1993) Pathways of lysozyme evolution inferred from the sequences of cytochrome $b$ in birds. J. Mol. Evol. 37: 367-379.

Miyaki, C. Y., Matioli, S. R., Burke, T. and Wajntal, A. (1998) Parrot evolution and paleogeographical events: mitochondrial DNA evidence. Mol. Biol. Evol. 15: 544-551.

Nardelli, P. M. (1993) A preservação do Mutum-de-Alagoas, Mitu mitu. Queimados, RJ: Semana Ilustrada Editorial.

Pereira, S. L. and Wajntal, A. (1999) Reintroduction of guans of the genus Penelope (Cracidae, Aves) in reforested areas in Brazil: assessment by DNA fingerprinting. Biol. Conserv. 87: 31-38.

Pereira, S. L. and Wajntal, A. (2001a) Studies of captive stocks of the endangered Redbilled Curassow (Crax blumenbachii) suggest that this species in not depleted of genetic variability. Pp. 112-123 in D. M. Brooks and F. Gonzalez-Garcia, eds. Cracid ecology and conservation in the new millenium. Houston, TX: Houston Museum (Misc. Publ. Nat. Sci. 2).

Pereira, S. L. and Wajntal, A. (2001b) Estimates of the genetic variability in a natural population of Bare-faced Curassow Crax fasciolata (Aves, Galliformes, Cracidae). Bird Conserv. Internatn. 11: 301-308.

Pereira, S. L., Miyaki, C. Y. and Wajntal, A. (1996) DNA fingerprinting in the rare BlackFronted Piping Guan Pipile jacutinga (Cracidae. Aves) Rev. Brasil. Biol. 56: 783-791.

Pinto, O. (1952) Redescobrimento de Mitu mitu (Linné) no nordeste do Brasil (Est. de Alagoas). Prova da independência de Mitu tuberosus (Spix) como espécie à parte. Pap. Avuls. Dep. Zool. São Paulo 10: 325-334. 
Rave, E. (1995) Genetic analysis of wild populations of Hawaiian geese using DNA fingerprinting. Condor 97: 82-90.

Rave, E., Fleischer, R. C., Duvall, F. and Black, J. M (1995) Genetic analysis through DNA fingerprinting of captive populations of Hawaiian geese. Conserv. Biol. 8: 744-751.

Roelke, M. E., Martenson, J. S. and O'Brien, S. J. (1993) The consequences of demographic reduction and genetic depletion in the endangered Florida panther. Curr. Biol. 3: 340350.

Sambrook, J., Fritsch, F. and Maniats, T. (1989) Molecular cloning: a laboratory manual. Second edition. Cold Spring Harbor, NY: Cold Spring Harbor Laboratory Press.

Sick, H. (1997) Ornitologia Brasileira, uma introdução. Rio de Janeiro: Ed. Nova Fronteira.

Sick, H. (1980) Characteristics of the Razor-billed Curassow Mitu mitu mitu. Condor 82: 227-228.

Sundt, R. C., Dahle, G. and Naevdal, G. (1994) Genetic variation in the hooded seal, Cystophora cristata, based on enzyme polymorphism and multi-locus DNA fingerprinting. Hereditas 121: 147-155.

Swofford, D. L. (2001) PAUP*, Phylogenetic Analysis Using Parsimony (*and related methods), version 4.o b8. Sunderland, MA: Sinauer Associates.

Tegelstrom, H. and Sjoberg, G. (1995) Introduced Swedish Canada geese (Branta canadensis) have low levels of genetic variation as revealed by DNA fingerprinting. $J$. Evol. Biol. 8: 195-207.

Teixeira, D. M. (1986) The avifauna of the north-eastern Brazilian Atlantic Forest: a case of mass extinction? Ibis 128, 167-168.

Teixeira, D. M. (1992) As fontes do paraíso - um ensaio sobre a ornitologia no Brasil holandês (1624-1654). Rev. Nordestina Biol. 7: 1-219.

Templeton, A. R. and Read, B. (1983) The elimination of inbreeding depression in a captive herd of Speke's gazelle. Pp. 241-261 in C. M. Schoenwald-Cox, S. M. Chambers, B. MacBryde and L. Thomas, eds. Genetics and conservation: a reference for managing wild animal and plant populations. London: Benjamin/Cummings.

Westneat, D. F. (1990) Genetic parentage in the Indigo Bunting: a study using DNA fingerprinting. Behav. Ecol. Sociobiol. 27: 67-76.

Wetton, J. H., Carter, R. E., Parkin, D. T. and Walters, D. (1987) Demographic study of a wild House Sparrow population by DNA fingerprinting. Nature 327: 147-149.

Zink, R. M. and Blackwell-Rago, R. C. (2000) Species limit and recent population history in the Curve-billed Trasher. Condor 102: 881-886.

ERWIN TRAMONTINI GRAU, SÉRGIO LUIZ PEREIRA and ANITA WAJNTAL ${ }^{1}$

Departamento de Biologia, Instituto de Biociências, Universidade de São Paulo. Rua do Matão, 277, São Paulo, SP, Brazil, CEP: 05508-900.

LUÍS FÁBIO SILVEIRA

Departamento de Zoologia, Instituto de Biociências, Universidade de São Paulo, São Paulo. Rua do Matão 321, Travessa 14, São Paulo, SP, Brazil, CEP: 05508-90o. E-mail: lfsilveira@uol.com.br

${ }^{1}$ Author for correspondence; e-mail: aniwa@usp.br; fax: 551130917553.

Received 9 May 2002; revision accepted 4 December 2002 